\title{
Positive Impact of COVID-19 Lockdown on Heavy Metals in Groundwater and Possible Health Risks for Human beings in an Industrialized City of South India
}

Karunanidhi Duraisamy ( $\nabla$ karunasamygis@gmail.com )

Sri Shakthi Institute of Engineering and Technology https://orcid.org/0000-0002-4722-9043

Aravinthasamy Palanisamy

Sri Shakthi Institute of Engineering and Technology

Shankar Karuppannan

Adama Science and Technology University

Subramani Thirumalaisamy

Anna University Chennai

Raj Setia

Punjab Remote Sensing Centre

\section{Research Article}

Keywords: Groundwater, Heavy metals, Microbial population, Health risk assessment, Coimbatore city, South India

Posted Date: February 16th, 2021

DOI: https://doi.org/10.21203/rs.3.rs-196307/v1

License: (c) (i) This work is licensed under a Creative Commons Attribution 4.0 International License.

Read Full License 
1 Positive impact of COVID-19 lockdown on heavy metals in groundwater and

2 possible health risks for human beings in an industrialized city of South India

Karunanidhi Duraisamy ${ }^{*}$, Aravinthasamy Palanisamy ${ }^{1}$, Shankar Karuppannan ${ }^{2}$, Subramani Thirumalaisamy ${ }^{3}$, Raj Setia ${ }^{4}$,

$7 \quad{ }^{1}$ Department of Civil Engineering, Sri Shakthi Institute of Engineering and Technology

8 (Autonomous), Coimbatore - 641062, India.

$9 \quad{ }^{2}$ Department of Applied Geology, School of Applied Natural Science, Adama Science and 10 Technology University, P.O.BOX 1888, Adama, Ethiopia.

11

$12{ }^{3}$ Department of Geology, CEG, Anna University, Chennai - 600025, India.

$13{ }^{4}$ Punjab Remote Sensing Centre, Ludhiana, India. 


\section{ABSTRACT}

In this investigation, positive impact of COVID-19 lockdown on heavy metals concentration and biological parameters in the groundwater samples of Coimbatore city of South India. The groundwater samples $(n=15)$ were obtained from shallow-open wells before lockdown (24-25 January 2020) and after lockdown (2-3 June 2020) periods. These samples were analysed for heavy metals (Fe, Mn, Ni, $\mathrm{Cr}$ and $\mathrm{Pb})$ and biological parameters (E. coli, Fecal coliforms, Fecal 37 streptococci and Total coliforms). Fe concentration was within the permissible limit but, the concentrations of $\mathrm{Mn}, \mathrm{Ni}, \mathrm{Cr}$ and $\mathrm{Pb}$ were above the allowable limits for drinking uses as per the WHO. However, after lockdown the number of samples crossing the cutoff limit had considerably decreased (Mn: 2 to 0 ; $\mathrm{Ni}: 13$ to 10 ; $\mathrm{Cr}: 7$ to 5; $\mathrm{Pb}: 13$ to 8 ). The spatial distribution of heavy metal pollution index (HPI) revealed that $176.75 \mathrm{~km}^{2}(67.4 \%)$ and $85.35 \mathrm{~km}^{2}(32.6 \%)$ areas fell under unsuitable and very poor categories, respectively, during pre-lockdown period, whereas 138.23 $\mathrm{km}^{2}(52.6 \%), 118.98 \mathrm{~km}^{2}(45.3 \%)$ and $4.89 \mathrm{~km}^{2}(2.1 \%)$ areas fell under very poor, poor and good categories, respectively, during post-lockdown period. Similarly, Total coliform, Fecal coliform and $E$. coli had decreased distinctly due to the pandemic lockdown. Therefore, shutdown of small and large-scale industries during the lockdown period had improved the groundwater quality. and $73 \%$ of post-lockdown samples possessed non-carcinogenic risks (HI > 1) for children, female and male categories, respectively.

50 Keywords: Groundwater; Heavy metals; Microbial population; Health risk assessment; 51 Coimbatore city; South India. 
The precipitous growth of industrialization and urbanization in the last few decades has severely contaminated the natural environmental components (soil, air, water, etc.) with various

57 pollutants throughout the globe (Rahman et al. 2020). Among different pollutants, heavy metals

58 are considered to be the most dangerous contaminants because of their toxic effects at higher concentrations and persistence in natural components (Elumalai et al. 2017). The main origin of the heavy metals in water is parent rock materials. The natural concentration of heavy metals in water is usually low (Mukherjee et al. 2019), but their concentration increases many folds due to anthropogenic activities (e.g. extensive agro-chemicals based agriculture, industrial and urban wastewater discharges in water sources etc). Water contamination with heavy metals is a primary environmental concern in both developed and developing countries (Khan et al. 2013). A numerous investigation on contamination of heavy metals in surface water and groundwater indicate that anthropogenic factors such as municipal solid waste, leachate, manufacturing

67 industries, fertilizers, and household waste are the important sources of contamination of groundwater (Romic and Romic 2003; Sajil Kumar et al. 2012; Mukherjee et al. 2019). The heavy metals released from anthropogenic sources may infiltrate through leaching (Shankar, 2019), The infiltration of heavy metals to aquifers might lead to several health problems because of intake of

71 heavy metals via water used for drinking purposes (Balakrishnan and Ramu 2016). In addition to 72 health risks due to heavy metals, many bacterial diseases are transmitted through waste waters 73 discharged into groundwater system (Gao et al. 2020). Therefore, assessment of biological quality 74 of water is also important because several bacterial illnesses (like cholera, bacillary dysentery and 75 typhoid fever) are transmitted through contaminated water (Cabral 2010). Several studies 76 conducted in an around the world have characterised the heavy metal contamination in drinking 77 water (Prasanna et al. 2012; Wagh et al. 2018; Edet and Offiong 2002), but the effect of COVID- 
19 lockdown on heavy metals contamination and microbiological quality of water has not been

79 assessed.

In India, industries were closed due to COVID-19 because the focus was on containing the

81 spread via quarantines and national lockdowns (Hamzelou 2020). The Indian government announced lockdown in the country from 24 March to 31 May in four phases, and industries were allowed to open in many places from $1^{\text {st }}$ June 2020 onwards. However, colleges, schools, malls, 84 public transports, markets, and hotels were closed during the lockdown period. Many studies have analysed the gaseous concentration in the atmosphere before and after the COVID-19 lockdown period (Bagyaraj et al. 2020; Ghosh et al. 2020; Das et al. 2020), but there is no comparative

87 investigation on the evaluation of heavy metal pollution and microbiological quality of groundwater during the COVID-19 pandemic lockdown. It was hypothesized that heavy metal contamination in groundwater will be reduced, but microbiological quality of groundwater will be improved during and just after the COVID-19 lockdown period. Therefore, we studied the heavy

91 metal contamination and microbiological quality of groundwater before and after the COVID-19

92 lockdown period in Coimbatore (largest Industrialized city) region of southern India. In addition

93 to this, human health risks were also calculated and the multivariate statistics were used to identify

94 the probable source of metals in the groundwater of the city of Coimbatore before and after the 95 COVID-19 lockdown periods.

\section{MATERIALS AND METHODS}

\section{Study area}

98 Coimbatore is the largest industrial city in the state of Tamil Nadu and is also referred as 99 the state of Manchester. The study area is situated between the latitudes $10^{\circ} 52^{\prime} 30^{\prime \prime} \mathrm{N}$ and $11^{\circ}$ $1004^{\prime} 30^{\prime \prime} \mathrm{N}$, and longitudes between $76^{\circ} 51^{\prime} 0^{\prime \prime} \mathrm{N}$ and $77^{\circ} 3^{\prime} 0^{\prime \prime} \mathrm{N}$ (Figure 1). The total area is $262 \mathrm{~km}^{2}$. 
101

102

103

104

105

106

107

108

109

110

111

112

113

114

115

116

117

118

119

120

121

122

123

124

The average annual rainfall ranges from 550 to $900 \mathrm{~mm}$, and temperature fluctuates from 19.8 to $35.9^{\circ} \mathrm{C}$. The land use/land cover $(\mathrm{Lu} / \mathrm{Lc})$ of the area was classified using Landsat 8 satellite data (Figure 1). The major Lu/Lc cover is settlement (46.4\%) followed by agriculture (23.7\%), industry (5.9\%) and other classes like follow land (13.4\%), water bodies (2.03\%) and hills (8. 53\%). The major soil types in the region are red non-calcareous, red calcareous, black soil, and colluvial soil. The major industries are textile, dyeing, electroplating, petrochemicals, steel, building materials, chemicals and fertilizers, plastic and sugar and metal casting. In the current situation, more than 25.000 small, medium, large-scale factories, and textile mills are located in the district of Coimbatore. The major rock types in this area are hornblende biotite gneiss, charnockite, granite, and fissile hornblende biotite gneiss (GSI 1995). Groundwater of the area arises from weathered rocks, and the major aquifer system is under unconfined nature. However, the deep aquifer (fracture aquifer) is under semi-confined to confined in character. The specific yield of open wells varies from 50 to 300 liters per minute $(\mathrm{lpm})$. The transmissivity $(\mathrm{T})$ of this region varies from 1.49 to $164.18 \mathrm{~m}^{2} /$ day.

\section{Sample collection and analytical procedure}

Geo-tagged groundwater samples $(n=15)$ were taken from open wells before (January, 2020) and after COVID-19 (June, 2020) lockdown periods. The sampling and analysis of water followed the standard guidelines specified by APHA 2005. Groundwater samples were taken from the field using $500 \mathrm{ml}$ of pre-washed Teflon bottles. One portion of the samples were acidified with concentrated nitric acid (below $\mathrm{pH}$ of 2.0) to reduce the absorption and precipitation on the bottle walls, and another portion of the water samples were not acidified. In addition, the collected water samples were tightly wrapped and moved to the laboratory, and placed in an ice jacket at $4^{\circ} \mathrm{C}$ until tested These samples were analysed for heavy metals ( $\mathrm{Fe}, \mathrm{Cr}, \mathrm{Pb}, \mathrm{Mn}$, and $\mathrm{Ni}$ ) using Atomic Absorption Spectroscopy (AAS) method (Perkin Elmer Analyst 700). Groundwater 
samples were also analysed for biological parameters (Total coliform bacteria, Escherichia coli /

126 E.coli, Fecal streptococci and Fecal coliform bacteria) using the Most Probable Number (MPN)

127 technique.

\section{Spatial and Statistical analyses}

Inverse Distance Weighted was used to study the spatial variation heavy metals in HPI using ArcGIS version 10.2.1. Pearson correlation coefficient was calculated to obtain the relationship among heavy metals using SPSS (version=20) software package. Principal

132 Component Analysis (PCA) was used for source detection of heavy metals in groundwater of the 133 area.

\section{Heavy metal pollution index (HPI)}

HPI was used to identify the impacts of distinct heavy metals on the quality of groundwater.

The HPI was calculated using the equation 1 (Mohan et al. 1996).

$$
H P I=\frac{\sum_{i=1}^{n} W_{i} Q_{i}}{\sum_{i=1}^{n} W_{i}}
$$

$\left(\mathrm{W}_{\mathrm{i}}\right)$ denotes unit weight using Equation. (2):

$$
\mathrm{w}_{i}=\frac{K}{S_{i}} \ldots \ldots \ldots \ldots \ldots
$$

140 (Qi) indicate sub-index of the parameter, which is calculated by Equation. (3)

$$
Q_{i}=\sum_{i=1}^{n} \frac{\left\{M_{i}(-) l_{i}\right\}}{S_{i}-l_{i}} \times 100
$$

$\mathrm{W}_{\mathrm{i}}$ indicate unit weight of the parameter (' $\mathrm{i}^{\text {th'}}$ ); $\mathrm{Q}_{\mathrm{i}}$ shows sub-index (' $\mathrm{i}^{\text {th' }}$ ) parameter; $\mathrm{n}$ is

143 the total number of parameters; $\mathrm{K}$ is the proportionality constant; $\mathrm{Mi}$, $\mathrm{Si}$ and Ii are the measured

144 values of heavy metals, standard values, and ideal values of the parameter, correspondingly. The 
value of HPI >100 in drinking water indicates serious impacts to the human system (Prasad and Bose 2001).

The spatial variations in HPI was studied using the Inverse Distance Weighted (IDW) method (spatial analyst tool) in ArcGIS (version=10.4) (e.g. Shankar and Kawo 2019 and Soujanya et al. 2020). IDW is an effective method for spatial interpolation of groundwater quality parameters (Karunanidhi et al. 2019; Kawo and Shankar 2018; Balamurugan et al. 2020).

\section{Health risk assessment}

The contamination of water with heavy metals may create harm to human health through multi-exposure pathways like breathing, intake, and dermal contact. The USEPA has developed models for the assessment of human health risks (Wu et al. 2012). Based on USEPA (USEPA 1989; 1995; 2014), the four important steps for health risk evaluation are: risk identification, evaluation of dose and response, exposure assessment, and risk categorization (Wu et al. 2020). In this study, the drinking exposure pathway was considered for health risk assessment.

Equation 4 calculated the non-carcinogenic risks through intake pathway;

$$
\text { Intake }_{\text {oral }}=\mathrm{C} \times \mathrm{EF} \times \mathrm{ED} \times \mathrm{IR} / \mathrm{BW} \times \mathrm{AT}
$$

Where $\mathrm{C}=$ concentration of heavy metal in water $(\mathrm{mg} / \mathrm{L})$,

$\mathrm{IR}=$ daily ingestion rate of water (liter/day), and it is 0.64 liter /day for children, 2 liters /day for male and 1.9 liters /day for female),

$\mathrm{EF}=$ Exposure frequency and its unit expressed as days/year. EF of the three age categories is 365 days or 1 year,

$\mathrm{ED}=$ Exposure duration of the assessment $(6$ years for children; 40 and 30 years for male and female, respectively)

$\mathrm{BW}=$ Bodyweight of different age groups $(15 \mathrm{~kg}$ for children, $70 \mathrm{~kg}$ for male and $55 \mathrm{~kg}$ 168 for female). 
170 female and 14600 days for male.

171 The non-carcinogenic risk quotient (HQ) through intake / oral pathway was computed

172 using the following equation:

$$
\mathrm{HQ}_{\text {oral }}=\frac{\text { Intake }_{\text {oral }}}{\mathrm{RfD}_{\text {oral }}} \ldots \ldots . . . .(5)
$$

175 for $\mathrm{Fe}, 0.024$ for $\mathrm{Mn}, 0.02$ for $\mathrm{Ni}, 0.003$ for $\mathrm{Cr}$ and 0.0014 for $\mathrm{Pb}$.

176 Hazard index (HI) was calculated using the equation (6)

$$
\mathrm{HI}_{\text {total }}=\sum_{j=1}^{n} \mathrm{HI}_{\mathrm{i}} \ldots \ldots \ldots(6)
$$

The values of $\mathrm{HI}_{\text {total }}$ more than 1 indicates severe non-carcinogenic risk.

\section{RESULTS AND DISCUSSION}

180

181

182

\section{Heavy metals in groundwater}

Table 1 displays the maximum, minimum, and mean values of heavy metals in groundwater samples before and after COVID-19 lockdown periods in the study area. Before COVID-19 lockdown, the Fe concentration in groundwater varied from 0.010 to $0.044 \mathrm{mg} / \mathrm{L}$ with the mean value of $0.026 \mathrm{mg} / \mathrm{L}$, whereas after COVID-19 lockdown, it varied from 0.005 to $0.041 \mathrm{mg} / \mathrm{L}$ with a of mean $0.021 \mathrm{mg} / \mathrm{L}$. In the study area, all the groundwater samples were below the allowable limit $(0.3 \mathrm{mg} / \mathrm{L})$ of WHO guidelines. The mean concentration of Fe in groundwater decreased after COVID-19 lockdown period compared to pre-COVID-19 lockdown (Figure. 2a).

The higher concentration of Fe causes stomach irritation and enhances the iron bacterium that influences the taste of water (Brindha et al. 2020). The concentration of $\mathrm{Mn}$ in groundwater varied from 0.055 to $0.41 \mathrm{mg} / \mathrm{L}($ mean $=0.123 \mathrm{mg} / \mathrm{L})$ before lockdown, and from 0.03 to 0.40 $\mathrm{mg} / \mathrm{L}(\mathrm{mean}=0.113 \mathrm{mg} / \mathrm{L})$ after COVID-19 lockdown period. It was found that $13 \%$ of the 
samples before lockdown and none of the samples after lockdown exceeded the permissible limit

193 of $0.4 \mathrm{mg} / \mathrm{L}$ recommended by WHO. Like Fe, Mn concentration in groundwater also decreased 194 after COVID-19 lockdown (Figure. 2b). Brindha et al. (2020) showed that Mn affects the taste of 195 water, and precipitates in food when used for food preparation and also promotes the growth of 196 algae in reservoirs.

Before and after COVID-19 lockdowns, the Ni concentration in groundwater was 0.01 to $1980.39 \mathrm{mg} / \mathrm{L}$ and 0.01 to $0.32 \mathrm{mg} / \mathrm{L}$, respectively. It was found that $87 \%$ of the samples surpassed 199 the permissible limit $(0.07 \mathrm{mg} / \mathrm{L})$ of $\mathrm{Ni}$ for drinking purposes before lockdown but after the 200 lockdown period only $67 \%$ of the samples surpassed. There were no significant changes in $\mathrm{Ni}$ 201 concentration in groundwater samples of all the sites except site no. 13 (Figure.2c). In the study 202 area, industries were closed from $25^{\text {th }}$ March to $31^{\text {st }}$ May 2020, and the samples were collected 203 during 24-25 January 2020 (before lockdown) and 2-3 June 2020 (after lockdown). Therefore, the 204 effect of industrial waste on Ni concentration was not observed. However, the possible sources of 205 Ni contamination in water are primarily agricultural activity in the area and domestic wastewater 206 effluents. It is well known that industries tend to increase Ni emissions to natural ecosystems, 207 where several nickel compounds are used for industrial and commercial purposes (Cempel and 208 Nikel 2006).

209 The concentration of $\mathrm{Cr}$ in groundwater ranged from 0.003 to $0.3 \mathrm{mg} / \mathrm{L}$ before lockdown 210 and from 0.010 to $0.15 \mathrm{mg} / \mathrm{L}$ after COVID-19 lockdown. The average concentration of $\mathrm{Cr}$ in 211 groundwater was decreased by $0.02 \mathrm{mg} / \mathrm{L}$ from before to after COVID-19 lockdown, which was 212 mainly due to closure of industries during the lockdown period (Figure.2d). As per the allowable 213 limit of $\mathrm{Cr}(0.05 \mathrm{mg} / \mathrm{L})$ in drinking water defined by WHO, 47\% and $33 \%$ of the samples crossed 214 the acceptable limit before and after lockdown, respectively. However, the possible sources of $\mathrm{Cr}$ 
215 include household waste, dyes, paints, ceramics and pottery (Patel et al. 2017; Sutherland et al. 216 2000).

217

218

219

220

221

222

223

224

225

226

227

228

229

230

231

232

233

234

235

236

237

238

The concentration of $\mathrm{Pb}$ in groundwater ranged from 0.011 to $0.188 \mathrm{mg} / \mathrm{L}$ before COVID19 lockdown and from 0.00 to $0.12 \mathrm{mg} / \mathrm{L}$ after COVID-19 lockdown. The mean concentration of $\mathrm{Pb}$ in groundwater was decreased by $0.11 \mathrm{mg} / \mathrm{L}$ from before to after COVID-19 lockdown (Figure.2e). As per the acceptable limit $(0.01 \mathrm{mg} / \mathrm{L})$ of $\mathrm{Pb}$ in drinking water suggested by WHO, $87 \%$ of the samples exceeded the acceptable limit before lockdown, but only $53 \%$ of the samples crossed the limit after lockdown. The possible sources of lead in water are old plumbing, animal and human excretion, disposal of materials containing lead batteries, pipes and paints at landfill sites and agricultural runoff containing phosphate fertilizers (Rajasekaran and Abinaya 2014; Boateng et al. 2019). The $\mathrm{Pb}$ concentration in drinking water $>0.01 \mathrm{mg} / \mathrm{L}$ may induce nervous problems in newborn kids, and in the fetus (WHO 2017). The average values of the heavy metals in this region are shown in figure $2 \mathrm{f}$.

\section{Spatial distribution, of heavy metal pollution index}

The HPI of groundwater samples ranged from 85.5 to 153 with an average of 101 before COVID-19 lockdown period, whereas it ranged from 42.4 to 98.5 with an average of 79.7 after COVID-19 lockdown. Based on HPI, the groundwater samples were categorized into 5 types: 'excellent' means less than 25, 'good' indicates 26 to 50, 'poor' indicates 51 to 75, 'very poor' ranges from 76 to 100 and 'unsuitable' means > 100. The HPI value was more than 100 in $27 \%$ of groundwater samples before COVID-19 lockdown, but it was less than 100 in all the samples after lockdown period. Similarly, $73 \%$ of the samples were classified as very poor before lockdown, but $47 \%, 40 \%$ and $13 \%$ of the samples were classified as very poor, poor and good after lockdown, respectively (Table 2). Spatial variations of HPI showed that groundwater quality was very poor over $176.75 \mathrm{~km}^{2}$ area (67.4\%) and unsuitable over $85.35 \mathrm{~km}^{2}$ area (32.6\%) before COVID-19 
lockdown (Figure 3a). The HPI spatial map of post-COVID-19 lockdown (Figure 3b) showed that there is a significant improvement in the groundwater quality. About $138.23 \mathrm{~km}^{2}(52.6 \%), 118.98$ $\mathrm{km}^{2}(45.3 \%)$ and $4.89 \mathrm{~km}^{2}(2.1 \%)$ areas, respectively, had very poor, poor and good types of groundwater as per HPI.

\section{Biological parameters in groundwater}

The concentration of Fecal coliform bacteria varied from 6.8 to $110 \mathrm{MPN} \mathrm{mL} / 1$ before lockdown and, from 4.6 to 74 MPN mL/l after the COVID-19 lockdown period. The Total coliform ranged from 2 to $118 \mathrm{MPN} \mathrm{mL} / \mathrm{l}$ before COVID-19 lockdown, and from 1.1 to $84 \mathrm{MPN} \mathrm{mL/l} \mathrm{after}$ the COVID-19 lockdown period. The average E. coli was $27.9 \mathrm{MPN} \mathrm{mL} / \mathrm{l}$ before COVID-19 lockdown and 19.5MPN mL/l after the lockdown (Figure 4). The variation between the before and during COVID -19 lockdown period, 37\%, 36\%,14\% decreased during lockdown period. The occurrence of E. coli is mainly associated with contamination sources like sewage and waste dumps (Keesari et al. 2015).

\section{Principal Component Analysis (PCA)}

The PCA analysis showed that $67 \%$ and $76.2 \%$ of the total variances were extracted from three and four principal components before and after lockdown periods, respectively. The loadings of component matrix showed that PC1 explained $2.09 \%$ of the variance and is dominated by $\mathrm{Mn}$ (positive correlation), Fecal streptococci (positive correlation), Ni (negative correlation) and Total coliform bacteria (negative correlation) before lockdown. After COVID-19 lockdown period, the PC1 explained $24.3 \%$ of the total variance, and the contributions of $\mathrm{Ni}$ and Fecal coliform bacteria were positive, but the contribution of $\mathrm{Mn}$ was negative. The contributions of $\mathrm{Ni}, \mathrm{Mn}$ and bacteria in PC1 were mainly from anthropogenic activities such as local waste disposal, industrial waste, sewage intrusion and synthetic chemical fertilizers. The PC2 explained $23.3 \%$ and $18.9 \%$ of the variances before and after lockdown periods, respectively (Figures 5a, 5b). The main contributions 
263

264

265

266

267

268

269

270

271

272

273

274

275

276

277

278

279

280

281

282

283

284

285

in PC2 were from Fe and $\mathrm{Cr}$ (positive correlation). The PC3 showed the positive loading of Pb and total coliform bacteria before lockdown (50.9\% of the total variance), and Fecal coliform and Escherichia coli after lockdown period (17.0\% of the total variance). After COVID-19 lockdown period, PC4 showed $16.1 \%$ of the variance with positive loadings for $\mathrm{Pb}$ and negative loadings for Fecal coliform bacteria (Table 3). These results show that industrial waste, sewage and sludge had significant impact on metal contamination in groundwater.

\section{Health risk assessment}

The HQ values were above one for $\mathrm{Ni}, \mathrm{Cr}$ and $\mathrm{Pb}$, and were in the order: $\mathrm{Pb}>\mathrm{Cr}>\mathrm{Ni}>\mathrm{Mn}>$ Fe. Before lockdown, the mean HQ among children was 0.0015 for Fe, 0.0.2095 for Mn, 0.4363 for $\mathrm{Ni}, 1.0138$ for $\mathrm{Cr}$ and 0.0 .1971 for $\mathrm{Pb}$. The mean value of $\mathrm{HQ}$ among female category was 0.00105 for $\mathrm{Fe}, 0.1331$ for $\mathrm{Mn}, 0.2776$ for $\mathrm{Ni}, 0.6450$ for $\mathrm{Cr}$ and 1.0924 for $\mathrm{Pb}$. The mean value of HQ among male was 0.0010 for Fe, 0.1401 for $\mathrm{Mn}, 0.2922$ for Ni, 0.6789 for $\mathrm{Cr}$ and 1.1499 for $\mathrm{Pb}$. The non-carcinogenic risk based on $\mathrm{HI}_{\text {total }}$ was calculated for five heavy metals. The range of $\mathrm{HI}_{\text {total }}$ for pre-COVID-19 groundwater samples was 1.2518 to $7.1634,0.7964$ to 4.5571 and 0.8383 to 4.7970 for children, female and male, respectively. In this, $93 \%, 87 \%, 80 \%$ of the samples exceeded the permissible limit $(\mathrm{HI}>1)$.

Similarly, the mean value of HQ among children was 0.0001 for Fe, 0.1925 for Mn, 0.38960 for $\mathrm{Ni}, 0.73062$ for $\mathrm{Cr}$ and 1.39050 for $\mathrm{Pb}$ in the post-COVID-19 samples. The mean value of HQ among female category was 0.0008 for Fe, 01227 for Mn, 0.2479 for Ni, 0.4648 for $\mathrm{Cr}$ and 0.8846 for $\mathrm{Pb}$. The mean value of HQ among male was 0.0008 for $\mathrm{Fe}, 0.1291$ for $\mathrm{Mn}$, 0.2609 for $\mathrm{Ni}, 0.4893$ for $\mathrm{Cr}$ and 0.9311 for $\mathrm{Pb}$. As per the results, $\mathrm{HI}_{\text {total }}$ in the post-COVID-19 samples varied from 1.16272 to $5.02000,0.7397$ to 3.1935 and 0.7786 to 3.3616 for children, female and male groups, respectively (Table 4). 
Among the category of children, the average $\mathrm{HQ}$ was above one for $\mathrm{Cr}$ and $\mathrm{Pb}$ in the pre-

287 lockdown samples, whereas HQ was greater than one for Pb alone in the post-lockdown samples.

288 For female and male categories, the average $\mathrm{HQ}$ was above one for $\mathrm{Pb}$ in the pre-lockdown

289 samples. The HI was above one in $87 \%, 80 \%, 73 \%$ for children, female and male in the pre-

290 COVID-19 lockdown samples, respectively. However, HI was more than one in 87\%, 80\%, 73\%

291 of the groundwater samples collected after lockdown for children, female and male, respectively.

292 CONCLUSIONS

In the Coimbatore city of south India, heavy metal concentration in groundwater $(n=15)$ is in the order of $\mathrm{Mn}>\mathrm{Ni}>\mathrm{Cr}>\mathrm{Pb}>\mathrm{Fe}$. Fe and $\mathrm{Mn}$ concentrations were below the acceptable values proposed for drinking by WHO except concentrations of Mn in 2 samples of postCOVID-19 lockdown. The lockdown has brought down the concentrations of heavy metals in groundwater of this region, and has significantly reduced the number of post-lockdown samples crossing the allowable limit for consumption (Ni: from 13 to 10; $\mathrm{Cr}$ : from 7 to 5; $\mathrm{Pb}$ : from 13 to 8). The spatial plot of heavy metal pollution index (HPI) indicated that unsuitable and very poor groundwater quality areas had decreased from $176.75 \mathrm{~km}^{2}(67.4 \%)$ to 0 and from 85.35 $\mathrm{km}^{2}(32.6 \%)$ to $138.23 \mathrm{~km}^{2}(52.6 \%)$, respectively. In addition to this, unsuitable and very poor groundwater quality areas were changed to poor $\left(118.98 \mathrm{~km}^{2} / 45.3 \%\right)$ and good $\left(4.89 \mathrm{~km}^{2} /\right.$ $2.1 \%$ ) categories in the post-lockdown period. This was resulted by the closure of small and large-scale industries during the lockdown period. Similarly, the mean population of Fecal coliform, Total coliform and Escherichia coli (E. coli) had decreased from 74.29 to 45.31 MPN/mL/l, from 66.77 to $45.21 \mathrm{MPN} / \mathrm{mL} / 1$, and from 27.93 to $19.53 \mathrm{MPN} / \mathrm{mL} / 1$, respectively, due to the COVID-19 lockdown. Principle component analysis (PCA) showed that $67 \%$ and $76.2 \%$ of the total variances were extracted from three and four principal components, respectively, in pre- and post-lockdown periods. The hazard index indicated that the number of 

samples possessing non-carcinogenic risk $(\mathrm{HI}>1)$ has reduced from $93 \%$ to $87 \%$, from $87 \%$ to $80 \%$ and from $80 \%$ to $73 \%$, respectively, for children, female and male categories due to the

312 lockdown effect. This shows children are more prone to non-carcinogenic risk than female and 313 male. The results suggest that heavy metal contamination in groundwater is mainly associated 314 with industrial effluents, sewage, sludge and dumping of municipal wastes. Though the COVID-19 pandemic has improved the groundwater quality, this is not the solution to improve the quality of groundwater as it has impacted millions across the world and has brought the economy to a grinding halt. However, the results will be useful for devising the remediation strategies to reduce the multi-metal contaminations in groundwater, and also the epidemiological methods to prevent the human health risks. Further, the outcome of this study insists the responsibilities of industrial, municipal and agricultural sectors to keep the environment pollution free and to ensure the supply of potable water to the people of this city.

\section{Conflict of interest}

The authors declare that they have no known competing financial interests or personal

324 relationships that could have appeared to influence the work reported in this paper.

\section{Funding:}

326 The present work did not receive any financial assistance from any funding agency.

327 Data Availability: Not applicable.

328 Ethical approval: Not applicable.

329 Consent to participate: Not applicable.

330 Consent for publication: Not applicable.

331 Code availability: Not applicable. 


\section{Author Contributions}

Karunanidhi Duraisamy: writing-original draft, conceptualization, investigation, writing-review and editing, and supervision. Aravinthasamy Palanisamy: data curation, methodology, resources, writing-original draft and software. Shankar Karuppannan: formal analysis and. Subramani Thirumalaisamy: writing-review and editing, methodology, and formal analysis. Raj Setia: writing-review and editing.

\section{References}

APHA, (2005). Standard Methods for the Examination of Water and Wastewater, twentyfirst ed. American Public Health Association/American Water Works Association/ Water Environment Federation, Washington

Bagyaraj, M., Shankar, K., Alemayehu T, M., Muthukumarasamy, R., Gnanachandrasamy, G. (2020). Distribution and Trend Analysis of COVID-19 in India: Geospatial Approach. J. Geographical Studies, 4(1), 1-9.

Balakrishnan, A., Ramu, A. (2016). Evaluation of heavy metal pollution index (HPI) of groundwater in and around the coastal area of Gulf of Mannar biosphere and Palk Strait. J Adv Chem Sci 2(3):331-333

Balamurugan, P., Kumar, P.S., Shankar, K., Nagavinothini, R., Vijayasurya, K., (2020). NonCarcinogenic Risk Assessment of Groundwater in Southern Part of Salem District in Tamilnadu, India. Journal of the Chilean Chemical Society, 65.1: 4697-4707. 1. http://dx.doi.org/10.4067/S0717-97072020000104697 
Boateng, T.K., Opoku, F., Akoto, O. (2019). Heavy metal contamination assessment of groundwater quality: a case study of Oti landfill site, Kumasi. Appl Water Sci 9:1-15. https://doi.org/10.1007/s13201-019-0915-y

Brindha, K., Paul, R., Walter, J., Tan, M. L., Singh, M. K. (2020). Trace metals contamination in groundwater and implications on human health: comprehensive assessment using hydrogeochemical and geostatistical methods. Environmental Geochemistry and Health.doi:10.1007/s10653-020-00637-9

Cabral, J. P. S. (2010). Water Microbiology. Bacterial Pathogens and Water. International Journal of Environmental Research and Public Health, 7(10), 3657-3703. doi:10.3390/ijerph7103657

Cempel, M., Nickel, G., (2006). Nickel: a review of its sources and environmental toxicology. Polish J. Environ. Stud. 15 (3), 375-382.

Das, S., Das, S., Ghangrekar, M. M. (2020). The COVID-19 pandemic: biological evolution, treatment options and consequences. Innovative Infrastructure Solutions, 5(3). doi:10.1007/s41062-020-00325-8

Edet, A.E., Offiong, OE. (2002). Evaluation of water quality pollution indices for heavy metal contamination monitoring. A study case from Akpabuyo-Odukpani area, Lower Cross River Basin (south-eastern Nigeria). Geo J 57:295-304. https ://doi.org/10.1023/ B:GEJO.00000 07250.92458 .de

Elumalai, V., Brindha, K., Lakshmanan, E. (2017). Human exposure risk assessment due to heavymetals in groundwater by pollution index and multivariate statistical methods: a case study from South Africa. Water, 9, 234.https://doi.org/10.3390/w9040234. 
374 Gao, Y., Qian, H., Ren, W., Wang, H., Liu, F., Yang, F. (2020). Hydrogeochemical 375 characterization and quality assessment of groundwater based on integrated-weight water quality index in a concentrated urban area. J Clean Prod. https ://doi.org/10.1016/j.jclep ro.2020.121006

378 379 380 381 382 383 384 385 386 387

Ghosh, S., Das, A., Hembram, T. K., Saha, S., Pradhan, B., Alamri, A. M. (2020). Impact of COVID-19 Induced Lockdown on Environmental Quality in Four Indian Megacities Using Landsat 8 OLI and TIRS-Derived Data and Mamdani Fuzzy Logic Modelling Approach. Sustainability, 12(13), 5464. doi:10.3390/su12135464

GSI, (1995). Published by the Director General Geological Survey of India on. Geological and Mineral Map of Tamil Nadu and Pondicherry, vol. 1, p. 500, 000 scale.

Hamzelou, J., (2020). World in lockdown. New Sci. https://doi.org/10.1016/s0262-4079(20) 30611-4.

Karunanidhi, D., Aravinthasamy, P., Subramani, T., Wu, J., Srinivasamoorthy, K., (2019). Potential health risk assessment for fluoride and nitrate contamination in hard rock aquifers of Shanmuganadhi River basin, South India. Hum. Ecol. Risk Assess. 25 (1-2), 250-270. https://doi.org/10.1080/10807039.2019.1568859

Kawo, N.S., Shankar, K. (2018). Groundwater quality assessment using water quality index and GIS technique in Modjo River Basin, Central Ethiopia. J Afr Earth Sci 147:300-311. https://doi.org/10.1016/j.jafrearsci.2018.06.034

Keesari, T., Ramakumar, K. L., Prasad, M. B. K., Chidambaram, S., Perumal, P., Prakash, D., Nawani, N. (2015). Microbial Evaluation of Groundwater and its Implications on Redox 
Condition of a Multi-Layer Sedimentary Aquifer System. Environmental Processes, 2(2), 331-346. doi:10.1007/s40710-015-0067-5

Khan, I., Javed, A., Khurshid, S. (2013). Physico-chemical analysis of surface and groundwater around Singrauli coal field, District Singrauli, Madhya Pradesh, India. Environmental Earth Sciences, 68(7), 1849-1861

Mohan, S.V., Nithila, P., Reddy, S.J. (1996). Estimation of heavy metal in drinking water and development of heavy metal pollution index. J Environ Sci Health 31(2):283-289.

Mukherjee, I., Singh, U. K., Singh, R. P., Anshumali, Kumari, D., Jha, P. K., Mehta, P. (2019). Characterization of heavy metal pollution in an anthropogenically and geologically influenced semi-arid region of east India and assessment of ecological and human health risks. Science of The Total Environment, 135801. doi:10.1016/j.scitotenv.2019.135801

Patel. P., Raju, N.J., Reddy, BSR., Suresh, U., Sankar, D.B., Reddy, T.V.K. (2017). Heavy metal contamination in river water and sediments of the Swarnamukhi River Basin, India: risk assessment and environmental implications. Environ Geochem Health 40(2):609-623.

Prasad, B., Bose, J.M. (2001). Evaluation of heavy metal pollution index for surface and spring water near a limestone mining area of the lower Himalayas. Environ Geol 41:183-188.

Prasanna, M.V., Praveena, S.M., Chidambaram, S., Nagarajan, R., Elayaraja, A. (2012). Evaluation of water quality pollution indices for heavy metal contamination monitoring: a case study from Curtin Lake, Miri City, East Malaysia. Environ Earth Sci 67:1987-2001. https ://doi.org/10.1007/s1266 5-012-1639-6

Rahman, M. A. T. M. T., Paul, M., Bhoumik, N., Hassan, M., Alam, M. K., Aktar, Z. (2020). Heavy metal pollution assessment in the groundwater of the Meghna Ghat industrial area, 

Bangladesh, by using water pollution indices approach. Applied Water Science, 10(8). doi:10.1007/s13201-020-01266-4

Rajasekaran R., Abinaya M.M (2014). Heavy Metal Pollution in Ground Water - A Review, International Journal of Chem. Tech Research, 6: 5661-5664.

Romic, M., Romic, D. (2003). Heavy metal distribution in agricultural topsoil in urban area. Environ Geol 43(7):795-805

Sajil Kumar, P. J., Davis Delson, P., Thomas Babu, P. (2012). Appraisal of Heavy Metals in Groundwater in Chennai City Using a HPI Model. Bulletin of Environmental Contamination and Toxicology, 89(4), 793-798. doi:10.1007/s00128-012-0794-5

Shankar, B. S. (2019). A critical assay of heavy metal pollution index for the groundwaters of Peenya Industrial Area, Bangalore, India. Environmental Monitoring and Assessment, 191(5). doi:10.1007/s10661-019-7453-9

Shankar, K., Kawo, N. S., (2019). Groundwater quality assessment using geospatial techniques and WQI in North East of Adama Town, Oromia Region, Ethiopia.Hydrospatial Analysis, 3(1), 22-36. https://doi.org/10.21523/gcj3.19030103.

Sutherland, J.E., Zhitkovich, A., Kluz, T., Costa, M., (2000). Rats retain chromium in tissues following chronic ingestion of drinking water containing hexavelant chromium. Biol Trace Elem Res. 741, 41-53.

USEPA, (1989). Risk assessment guidance for superfund, volume 1: human health evaluation manual (part A). Office of Emergency and Remedial Response, Washington DC

USEPA. (1995). Water quality standards handbook: 2nd ed. EPA-823-B-94-005a,b. National Technical Information Service, Springfield, VA. 
439 USEPA. (2014). Drinking Water Contaminants. Available from: https://www.epa.gov/ground440 water-and-drinking-water/tableregulated-drinking-water-contaminants.

441 Wagh, V.M., Panaskar, D.B., Mukate, S.V., Gaikwad, S.K., Muley, A.A., Varade AM., (2018). 442 Health risk assessment of heavy metal contamination in groundwater of Kadava River Basin, Nashik, India. Modeling Earth Systems and Environment, 4(3), 969-980.

WHO, (2017). Guidelines for Drinking Water Quality: Fourth Edition Incorporating the First 446 Addendum. World Health Organization, Geneva.

447 Wu, J., Li, P., Qian, H. (2012). Study on the hydrogeochemistry and noncarcinogenic health risk 448 induced by fluoride in Pengyang County, China.Int J Environ Sci 2(3):1127-1134

449 Wu, J., Zhang, Y., Zhou, H. (2020). Groundwater chemistry and groundwater quality index 450 incorporating health risk weighting in Dingbian County, Ordos basin of northwest China. Geochemistry.https :// doi.org/10.1016/j.cheme r.2020.12560 7 


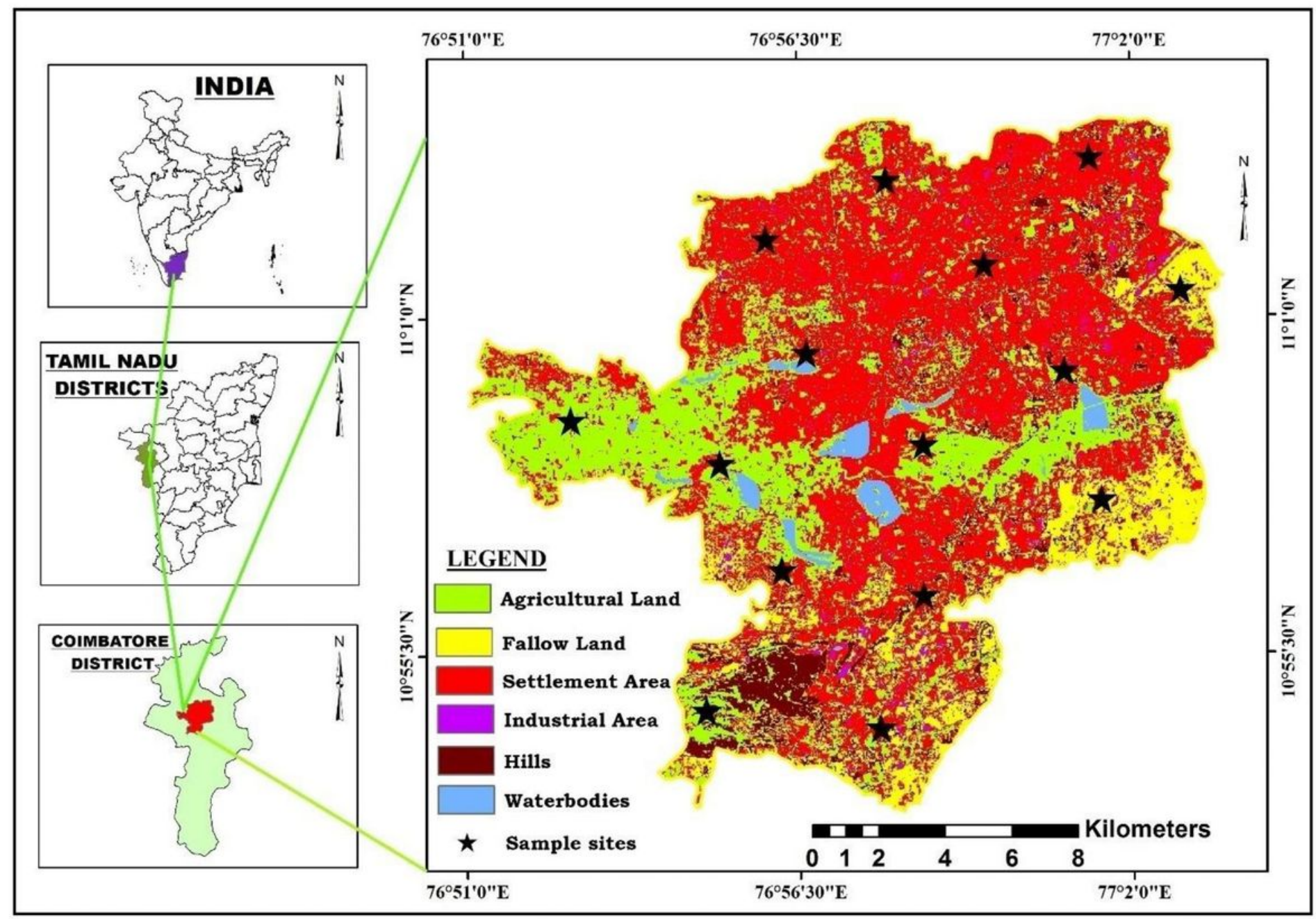

Figure 1

Land use/land cover map of the study area and sampling locations of pre- and post-COVID-19 lockdown. Note: The designations employed and the presentation of the material on this map do not imply the expression of any opinion whatsoever on the part of Research Square concerning the legal status of any country, territory, city or area or of its authorities, or concerning the delimitation of its frontiers or boundaries. This map has been provided by the authors. 


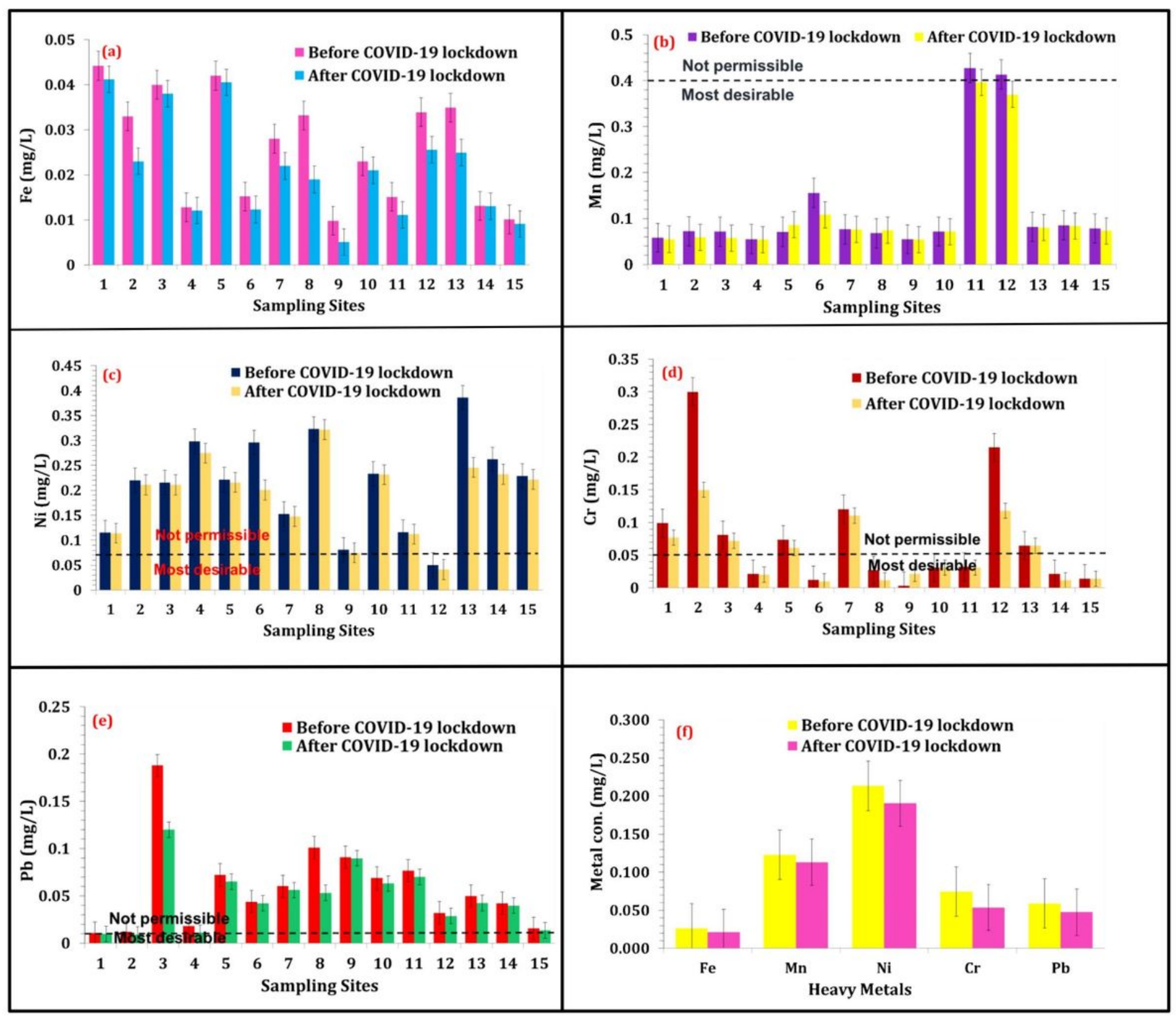

*All the 15 samples are within the most desirable limit of $0.3 \mathrm{mg} / \mathrm{L}$ based on Fe concentration

Figure 2

Heavy metal concentration in groundwater samples of pre- and post-COVID-19 lockdown 


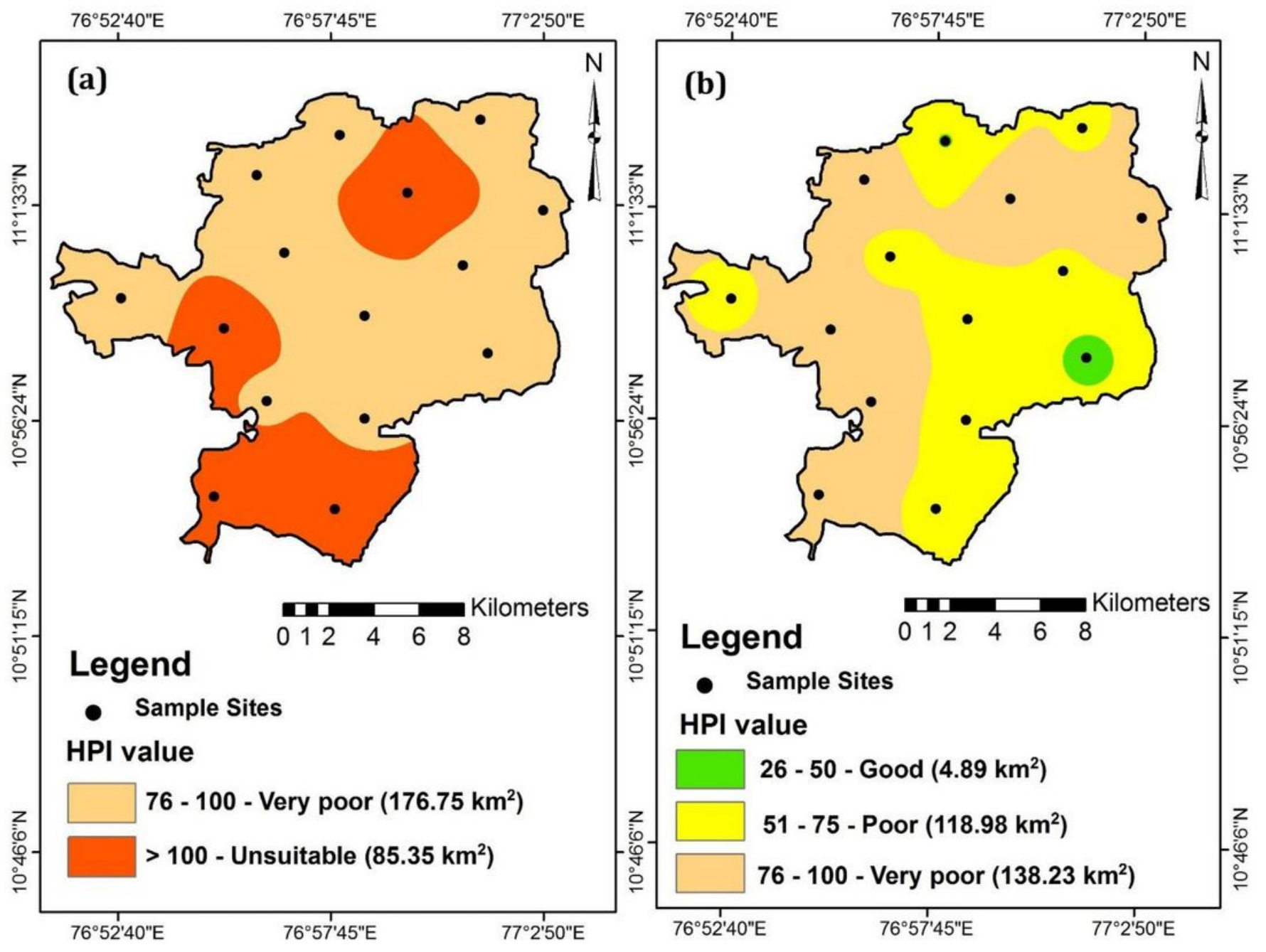

Figure 3

Spatial distributions of HPI (a) before COVID-19 lockdown, and (b) after COVID-19 lockdown. Note: The designations employed and the presentation of the material on this map do not imply the expression of any opinion whatsoever on the part of Research Square concerning the legal status of any country, territory, city or area or of its authorities, or concerning the delimitation of its frontiers or boundaries. This map has been provided by the authors. 


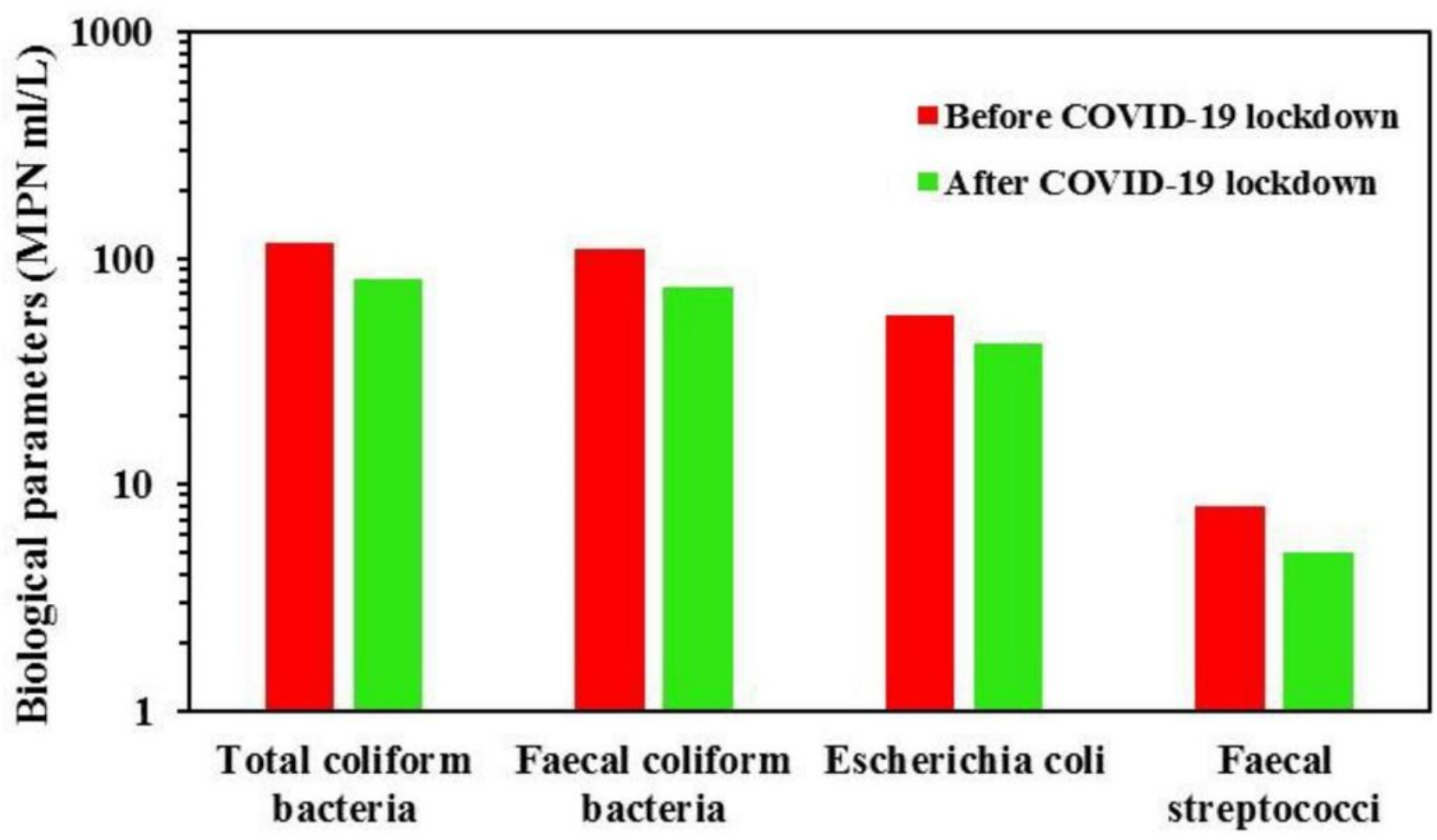

Figure 4

Biological parameters in the groundwater samples of pre- and post-COVID-19 lockdown
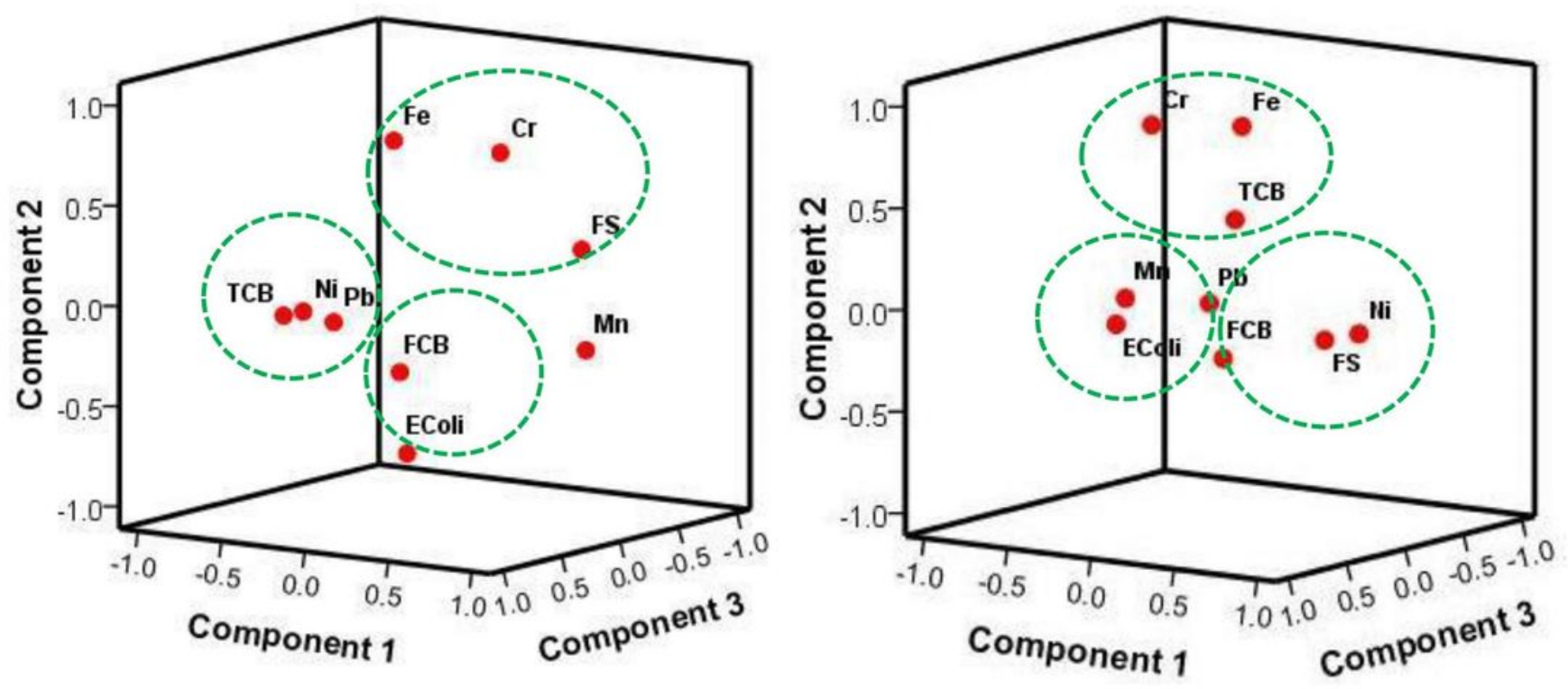

Figure 5 
PCA loading plots for (a) pre- and (b) post-COVID-19 lockdown samples. 